\title{
Production and partitioning of dry matter in leren [Calathea allouia (Aubl.) Lindl] ${ }^{1}$
}

\author{
Puran Bridgemohan ${ }^{2}$
}

J. Agric. Univ. P.R. 95(1-2):35-44 (2011)

\begin{abstract}
Leren [Calathea allouia (Aubl.) Lindl] is an under-exploited tropical tuber crop with potential for processing and as a substitute for water chestnuts. Shade affects the photosynthetic rate, and the growth and yields are variable. There is little research in the improvement on the agronomy of the crop. This study set out to understand the production and partitioning of assimilates as influencing crop yield through the manipulation of light, density, and nutritional factors, as well as to determine whether the rhizome of leren is the true sink or a filter/storage receptacle for tuberization. Several field and greenhouse studies were conducted over a two-year period at the Field Station of the University of Trinidad and Tobago. The treatments were light [full sunlight and shade $(50 \%)$ ], density ( 20.8 and 27.7 thousand plants per hectare), and fertilizer $\left[\mathrm{N}-\mathrm{P}_{2} \mathrm{O}_{5}-\mathrm{K}_{2} \mathrm{O}(13: 13: 20)\right]$ at varying rates $(0.0$ to 0.6 tha $)$. The leaf area, dry matter, and tuber yield were monitored. The results indicated that LAI varied between 1.38 (full sunlight) and 3.08 (shade) and was not influenced by crop nutrition. For both the greenhouse and field trials, rhizome dry matter accumulation and partitioning into tubers was higher in the shade treatments. Fertilizer application did not influence leaf growth or dry matter production (photosynthesis capacity) in the greenhouse trials, but more assimilates partitioned from rhizomes into the tubers in the lower crop density $\times$ intercrop. The partitioning of assimilates from the shoot to rhizome, and from rhizomes into tuber was more efficient in the shade $x$ intercrop treatments. The fertilizer application of 0.5 tha at the crop density of 20.8 thousand plants per hectare realized the highest dry matter $(1,066 \mathrm{~g} / \mathrm{plant})$ and tuber $(261.3 \mathrm{~g} / \mathrm{plant})$ yield. The study suggests that in leren, the rhizome and tubers are the primary and secondary sinks, respectively, with distinct partitioning of assimilates from shoot to rhizomes and from rhizomes to tubers.
\end{abstract}

Key Words: Leren, tuber crop, partitioning

\section{RESUMEN}

Producción y distribución de materia seca en lerén [Calathea allouia (Aubl.) Lindl]

El lerén [Calathea allouia (Aubl.) Lindl] es un tubérculo tropical con potencial para procesamiento y como un sustituto para las castañas de agua. La sombra afecta la tasa fotosintética del cultivo por lo que el

${ }^{1}$ Manuscript submitted to Editorial Board 1 December 2010.

${ }^{2}$ Assistant Professor, Crop Science and Technology, Biosciences, Agriculture and Food Technology, Waterloo Research Centre, University of Trinidad and Tobago, Waterloo Estates, Carapichaima, Trinidad. puran.bridgemohan@utt.edu.tt 
crecimiento y los rendimientos varían. Existe poca información en cuanto al mejoramiento agronómico de este cultivo. Este estudio se estableció para entender cómo, a través de la manipulación de la luz, densidad poblacional y factores nutricionales, la producción y distribución de los asimilatos afecta el rendimiento del cultivo. Al igual que para determinar si los rizomas del lerén son los verdaderos sumideros o si actúan como un filtro/almacenamiento para la tuberización. Se llevaron a cabo varios experimentos de invernadero y de campo durante un periodo de dos años en la Estación de Campo de la Universidad de Trinidad Tobago. Los tratamientos evaluados fueron luz [luz solar completa y sombra (50\%)], densidad poblacional $(20.8$ y 27.7 mil plantas por hectárea), y fertilización $\left[\mathrm{N}-\mathrm{P}_{2} \mathrm{O}_{5}-\mathrm{K}_{2} \mathrm{O}(13: 13: 20)\right]$ a varios niveles $(0.0$ a 0.6 tha). Se midió el área foliar, materia seca, y rendimiento de los tubérculos. Los resultados indicaron que el índice de área foliar varió entre 1.38 (luz solar) y 3.08 (sombra) y que el mismo no estuvo afectado por la nutrición del cultivo. Tanto para los ensayos de invernadero como los de campo, la acumulación de material seca en los rizomas y su distribución en los tubérculos fue mayor en los tratamientos con sombra que en aquellos bajo luz solar. La aplicación de fertilizantes no influenció el crecimiento de las hojas ni la producción de materia seca (capacidad fotosintética) en los ensayos en el invernadero, pero hubo mayor distribución de asimilatos desde los rizomas hasta los tubérculos cuando se usó una menor densidad poblacional $\times$ intercalado. La distribución de asimilatos de los tallos a los rizomas, y de los rizomas a los tubérculos fue más eficiente en los tratamientos de sombra $\times$ intercalado. La aplicación de fertilizante a la dosis de 0.5 t/ha a la densidad de 20.8 mil plantas por hectárea produjo la mayor cantidad de materia seca (1,066 $\mathrm{g} / \mathrm{planta})$ y el mayor rendimiento de tubérculos (261.3 $\mathrm{g} / \mathrm{planta})$. El estudio sugiere que en el lerén, los rizomas y tubérculos son los sumideros primarios y secundarios, respectivamente, con una distribución de asimilatos de tallos a rizomas y de rizomas a tubérculos.

Palabras clave: lerén, tubérculo, rendimiento

\section{INTRODUCTION}

Leren or Guinea arrowroot [Calathea allouia (Aubl.) Lindl] is an indigenous tuberous crop in the Caribbean and South America (Martin and Cabanillas, 1976; Bridgemohan, 2010). The herbaceous shrub belongs to the Marantace family, and is related to the West Indian arrow root [Maranta arundinacea. L (Leahy, 1991)]. Extended from the stem rhizomes by single strands of root are clusters of tubers. The crop is propagated by pieces of rhizomes which are fleshy sources of laevulose (Kay, 1973). The edible tubers are consumed as a seasonal snack or festival food (Everett, 1981) and contain acceptable levels of protein (13 to $16 \%$ ) and starch (6.6\%). The tubers can be canned to extend shelf life (L. Wickham, University of the West Indies, Trinidad, pers. comm., 2009) and are good substitutes for canned water-chestnuts (Bridgemohan, 2009).

The crop is cultivated either in pure stands or intercropped in small acreages with minimum fertilizer or pesticides inputs. Shade facilitates the growth of the plants, but it can tolerate full sunlight, provided that soil moisture, relative humidity, nutrients and drainage are not limiting (Bridgemohan, 2009). Crop yields vary between 2,000 to 
$8,000 \mathrm{~kg} / \mathrm{ha}$ (Martin and Cabanillas, 1976; Bridgemohan, 2009). In the Caribbean, the crop undergoes senescence during the harvest period (January to March), which is followed by a period of rhizome dormancy. The rhizome sprouts in the wet season (June/July) during the planting period and enters into a rapid and vigorous vegetative phase. Tuberization begins around September to October and continues for three to four months. This phase is initiated by the onset of the short days, thus suggesting the influence of photoperiodism.

An understanding of tuberization and the partitioning of assimilates is essential to improve yield (Tan and Hogan, 1968; Struik, 2007). The pattern of assimilate distribution is determined by rate of photosynthesis and the strength and proximity of the various sinks, which may be modified by environmental conditions and to some extent by the patterns of vascular connections.

It is the relative strength of the sink that largely determines the pattern of movement (Hofstra and Nelson, 1969; Van Delden, 2001). Sink strength is an important determinant of translocation pattern of primary partitioning of dry matter, and therefore of yield (Evans, 1978; Evans, 1986; Johnson et al., 1986). The potential growth rate of storage organs is an important determinant of sink strength, and this strength is dependent on translocation phloem unloading, enzymatic conversion, or the storage process, with or without hormonal influence (Peel and Ho, 1970; Struik, 2007).

Leren has multiple rhizomes per stool, which could result in intrarhizome competition, thus reducing the partitioning of assimilates into tubers. It is proposed that storage capacity in the rhizome or primary $\left(1^{\circ}\right)$ sink is more likely to limit yield in crops than the secondary translocation of assimilates from the rhizomes into the tubers or secondary $\left(2^{\circ}\right)$ sinks according to Yin and Schapendonk (2004).

The rhizome in leren acts as an intermediary between the shoot and tuber. As such, it is not clear whether the rhizomes are true sinks or a storage receptacle for tuberization. The objective of this study is to investigate the effect of varying crop nutrition, crop density and light (shade or full sunlight) and cropping system (pure stand or intercropping) on the production and partitioning of dry matter or assimilates into harvestable yield for leren.

\section{MATERIALS AND METHODS}

In two studies, several greenhouse, pot and field trials were conducted during the period June 2008 to March 2010 at the Centre of Bio-sciences, Agriculture, and Food Technologies, Waterloo Research Centre, The University of Trinidad and Tobago. 
Study 1: Effect of light and crop nutrition on dry matter production and partitioning

This study was conducted over two years (2008 and 2009); the trials were established in the month of June and harvested nine months later in the next year. Sprouted setts of leren stem rhizomes $(250 \mathrm{~g})$, treated with fungicide $\{25 \mathrm{ml} / \mathrm{L} \text { Alliete [aluminum tris (O-ethyl phosphonate) }]^{3}$ against soil-borne fungal diseases, were sown in pots filled with a sandy loam ( $50 \mathrm{~L}$ by volume). The pots were spaced out at $40 \mathrm{~cm} \times 40 \mathrm{~cm}$ to give a crop density of 16,000 plants per hectare.

The plants were subjected to two treatments: light (shade or full sunlight) and crop nutrition. The plants receiving the shade treatment (average maximum irradiance of $1200 \mu \mathrm{mol} / \mathrm{m}^{2} / \mathrm{s}$ ) were placed in a screen house enclosed and covered with 50\% saran cloth, whereas the full sunlight treatment was in the open with no obstructions. For the crop nutrition treatment we applied fertilizer $\left(13 \% \mathrm{~N}: 23 \% \mathrm{P}_{2} \mathrm{O}_{5}: 13 \% \mathrm{~K}_{2} \mathrm{O}\right)$ at rates of $0.0\left(\mathrm{~F}_{0}\right), 0.4\left(\mathrm{~F}_{1}\right), 0.5\left(\mathrm{~F}_{2}\right)$, and $0.6\left(\mathrm{~F}_{3}\right) \mathrm{t} / \mathrm{ha}$ (equivalent to $0.0,37.5,47.25$ and $56.25 \mathrm{~g} / \mathrm{plant}$ ) as a basal dosage at planting. The experimental design was a split-plot with light levels as the main plots (shade vs. sunlight), and the four fertilizer rates randomized within the main plots. Each treatment was replicated three times with a minimum of 16 potted plants per replicate. The plants in the pot trial were under greenhouse conditions and were manually irrigated daily with $500 \mathrm{ml}$ of water/plant. The experimental plot was bordered by two guard rows. Plant dry matter yield $\left(65^{\circ} \mathrm{C}\right.$ oven-drying for $72 \mathrm{~h}$ ) and leaf area (determined by using a leaf area meter -Type AAM-Hayashi Denko Co. Ltd. Japan) were used to monitor growth. The crop was harvested nine months after sowing when all the shoots and leaves were in complete senescence. The rhizomes were manually harvested and the tubers separated for yield analysis.

Study 2: Effect of cropping systems, nutrition and density on tuber yield

This study was conducted during the period June 2008 to February 2009 , and May 2009 to March 2010. The field trials were established at a spacing of $60 \times 60 \mathrm{~cm}$ and $60 \times 80 \mathrm{~cm}$ to give crop densities (D) of 27,778 and 20,833 plants per hectare, respectively. The soil type was Mc.Bean Estate sandy loam with an average CEC of $4.8 \mathrm{meq} / 100 \mathrm{~g}$, a pH (water) of 6.5 , and sand, silt, and clay content of $61.0,14.5$, and $24.5 \%$, respectively. The two cropping systems were pure stand (PS) or intercropped (IC) with pigeon pea (Cajanus cajan L. Millsp.). The pigeon peas were

\footnotetext{
${ }^{3}$ Company or trade names in this publication are used only to provide specific information. Mention of a company or trade name does not constitute a warranty of equipment or materials by the Agricultural Experiment Station of the University of Puerto Rico, nor is this mention a statement of preference over other equipment or materials.
} 
intercropped during planting at a spacing of $1 \mathrm{~m} \times 1.5 \mathrm{~m}$ between the leren plants. The pure stand treatment was 'open-field' receiving full sunlight. The crop nutrition treatment $(\mathrm{F})$ was a basal application of a compound fertilizer $\left(13: 23: 13 \mathrm{~N}-\mathrm{P}_{2} \mathrm{O}_{5}-\mathrm{K}_{2} \mathrm{O}\right)$ at three rates: $0.4\left(\mathrm{~F}_{1}\right), 0.5\left(\mathrm{~F}_{2}\right)$, and $0.6\left(\mathrm{~F}_{3}\right) \mathrm{t} / \mathrm{ha}$, applied at planting. The experimental design was a split-split plot, where cropping systems were main plots, crop density (D) the subplots and crop nutrition (F) the sub-subplots with three replicates. The net experimental plot included a minimum of 12 plants for destructive sampling (DM and leaf area) and a similar number for tuber yield harvest. The trials were rain-fed; all weed control operations were done manually, and harvesting was similar to that of Study 1. All data were analyzed by using the MINITAB 15 statistical package.

\section{RESULTS AND DISCUSSION}

Study 1: Effect of light and crop nutrition on dry matter production and partitioning

Tables 1 and 2 present the effects of light (shade and full sunlight) and crop nutrition (fertilizer rates) on the production and partitioning of assimilates of leren at harvest. The leaf area index (LAI) recorded at harvest in full sunlight (1.38) was low as compared to that in the shade treatment (3.08), and was not influenced by crop nutrition.

The results indicated a lower level of dry matter accumulation in all plant parts in full sunlight compared to that of those in the shade treatments (Table 1). This difference is reflected more significantly in

TABLE 1.-Effect of light and crop nutrition on the production of assimilates of Calathea allouia.

\begin{tabular}{|c|c|c|c|c|c|}
\hline \multicolumn{2}{|c|}{ Treatments } & \multicolumn{4}{|c|}{ Dry Matter yield ( $\mathrm{g} /$ stool) } \\
\hline Light & Fertilizer ( $\mathrm{t} / \mathrm{ha}$ ) & rhizome & root & tuber & shoot \\
\hline Shade & $\begin{array}{l}0.0 \\
0.4 \\
0.5 \\
0.6\end{array}$ & $\begin{array}{l}393 \\
445 \\
572 \\
418\end{array}$ & $\begin{array}{l}32 \\
33 \\
40 \\
36\end{array}$ & $\begin{array}{l}107 \\
163 \\
255 \\
192\end{array}$ & $\begin{array}{l}143 \\
145 \\
219 \\
140\end{array}$ \\
\hline Sunligl & $\begin{array}{l}0.0 \\
0.4 \\
0.5 \\
0.6\end{array}$ & $\begin{array}{c}83 \\
126 \\
119 \\
139\end{array}$ & $\begin{array}{l}11 \\
19 \\
19 \\
20\end{array}$ & $\begin{array}{l}13 \\
25 \\
50 \\
14\end{array}$ & $\begin{array}{l}30 \\
87 \\
43 \\
94\end{array}$ \\
\hline Mean & & $\begin{array}{l}286.8 \\
{[96.23]}\end{array}$ & $\begin{array}{l}26.2 \\
{[3.09]}\end{array}$ & $\begin{array}{l}102.3 \\
{[30.72]}\end{array}$ & $\begin{array}{l}112.6 \\
{[20.69]}\end{array}$ \\
\hline
\end{tabular}

Values in parenthesis is S.E. 
TABLE 2.-Effect of light and crop nutrition on the partitioning of assimilates of Calathea allouia

\begin{tabular}{|c|c|c|c|c|}
\hline \multicolumn{2}{|c|}{ Treatment } & \multirow[b]{2}{*}{ Total dry matter yield ( $\mathrm{g} / \mathrm{stool}$ ) } & \multirow{2}{*}{$\begin{array}{l}\% \text { assimilates } \\
\text { partitioned shoot and rhizome }\end{array}$} & \multirow{2}{*}{$\begin{array}{l}\% \text { assimilates partitioned } \\
\text { between rhizome and tubers }\end{array}$} \\
\hline Light & Fertilizer $(\mathrm{t} / \mathrm{ha})$ & & & \\
\hline Shade & $\begin{array}{l}0.0 \\
0.4 \\
0.5 \\
0.6\end{array}$ & $\begin{array}{r}675 \\
706 \\
1086 \\
786\end{array}$ & $\begin{array}{l}58 \\
56 \\
52 \\
59\end{array}$ & $\begin{array}{l}21 \\
26 \\
29 \\
30\end{array}$ \\
\hline Sunlight & $\begin{array}{l}0.0 \\
0.4 \\
0.5 \\
0.6\end{array}$ & $\begin{array}{l}137 \\
257 \\
231 \\
268\end{array}$ & $\begin{array}{l}60 \\
50 \\
51 \\
52\end{array}$ & $\begin{array}{l}12 \\
14 \\
26 \\
24\end{array}$ \\
\hline Mean & & $\begin{array}{r}518.25 \\
(110.91)\end{array}$ & $\begin{array}{c}54.75 \\
(1.32)\end{array}$ & $\begin{array}{c}22.75 \\
(2.28)\end{array}$ \\
\hline
\end{tabular}

Values in parenthesis is S.E. 
tuber yields of the main treatments, regardless of the nutrient levels. There is a three- to four-fold increase in dry matter yield in the shade treatment parameters over that of the sunlight treatment.

The rhizome dry matter yield was significantly $(P \leq 0.05)$ higher for shade treatments (393 to $572 \mathrm{~g} / \mathrm{stool}$ ), compared to that of the sunlight ( 83 to $139 \mathrm{~g} /$ stool), and increased linearly with fertilizer (F) rates for both the shade and sunlight treatments (Equations 1 and 2, respectively).

$$
\begin{array}{lll}
\mathrm{Y}_{\text {shade }}=404+141 \mathrm{~F} & \mathrm{R}_{2}=70.87 \% & \text { Equation 1 } \\
\mathrm{Y}_{\text {sunlight }}=83.9+87.6 \mathrm{~F} & \mathrm{R}_{2}=95.2 \% & \text { Equation 2 }
\end{array}
$$

Fertilizer application did not influence the percentage assimilates partitioned between rhizome and root dry matter into tuber yield (21 to $30 \%$ ) for shade treatments, but in the presence of sunlight, tuber yield improved linearly up to the $0.5 \mathrm{t} / \mathrm{ha}$ treatment, and then declined significantly (Table 2). It appeared that translocation from shoot to rhizome was influenced more by light/shade than by nutrients.

Study 2: Effect of cropping systems, nutrition and density on tuber yield

Table 2 presents the effect of crop nutrition, density, and cropping systems on the production and partitioning of dry matter yield of leren. The results indicated that there was no significant variation in leaf area index (LAI) at harvest between fertilizer (F) treatments in the pure-stand (PS) for both densities (D) (Table 3). However, during the same period the LAI for the intercrop (IC) increased with crop density but was not affected by fertilizer application (Equation 3).

$$
\mathrm{LAI}_{[\mathrm{IC}]}=0.05-1.3 \mathrm{~F}+0.07 \mathrm{D} \quad \mathrm{R}^{2}=84.7 \% \quad \text { Equation } 3
$$

TABLE 3.-Effect of crop nutrition, density, intercropping and pure stand on the partitioning of dry matter yield in Calathea allouia.

\begin{tabular}{lccccccc}
\hline \multicolumn{2}{c}{ Treatments } & & \multicolumn{2}{c}{ Intercrop } & & \multicolumn{2}{c}{ Pure Stand } \\
\cline { 1 - 2 } \cline { 7 - 8 } $\begin{array}{l}\text { Density } \\
\text { (plants/ha)* }\end{array}$ & $\begin{array}{c}\text { Fertilizer } \\
\text { (t/ha) }\end{array}$ & & LAI & $\begin{array}{c}\text { Tuber Weight } \\
\text { (g/plant) }\end{array}$ & & LAI & $\begin{array}{c}\text { Tuber Weight } \\
\text { (g/plant) }\end{array}$ \\
\hline 20.8 & 0.4 & & 1.06 & 191.6 & & 0.84 & 115.9 \\
& 0.5 & & 0.99 & 261.3 & & 1.10 & 159.7 \\
& 0.6 & & 0.86 & 251.6 & & 1.10 & 218.7 \\
27.7 & 0.4 & & 1.52 & 117.6 & & 1.05 & 154.2 \\
& 0.5 & & 1.70 & 97.4 & & 1.04 & 133.6 \\
& 0.6 & & 1.20 & 183.8 & & 1.08 & 140.5 \\
S.E. & & & 0.054 & 0.15 & & 0.042 & 16.84 \\
\hline
\end{tabular}

*Thousand plants per hectare 
A similar trend was exhibited for shoot dry (SD) matter as there was no effect from the F or D treatments on the SD of Leren in the PS system. However, under the intercropping (IC) system, the SD increased with increasing crop density, but was unaffected by changes in fertilizer rates (Equation 4).

$$
\mathrm{SD}_{[\mathrm{IC]}}=1.4-2.5 \mathrm{~F}+1.37 \mathrm{D} \quad \mathrm{R}^{2}=84.7 \% \quad \text { Equation } 4
$$

This finding suggests that in the full sunlight of the PS system, the crop was less photosynthetically active than in the IC system, and this finding may be attributed to the observation that the leaves 'curled and wilted' at the slightest changes in soil moisture and ambient temperature. The field trials received a total of 34.22 inches of rainfall during the crop life with 38.4 rainy days over the nine months. The production of assimilates in the shade of the IC system was significantly higher $(P \leq 0.01)$ as the leaves apparently did not respond to soil or environmental changes.

The mean rhizome dry matter (RD) yield for the PS system (556.4 g) was higher than that of the IC system ( $410.5 \mathrm{~g})$, but was unaffected by crop density or fertilizer. The RD in the IC treatment followed a similar pattern to that of LAI and SD and decreased with increasing crop density (Equation 5).

$$
\mathrm{RD}_{[\mathrm{IIC]}}=651-70.1 \mathrm{~F}-8.56 \mathrm{D} \quad \mathrm{R}^{2}=87.4 \% \quad \text { Equation } 5
$$

The crop tuber (T) yield was influenced by both fertilizer rates and crop density. In the IC system, yield increased with fertilizer rates, but decreased with density (Equation 6), whereas in the PS system, there was a significant interaction of $\mathrm{D} \times \mathrm{F}$ (Equation 7).

$$
\begin{array}{lcc}
\mathrm{T}_{[\mathrm{IC]}]}=393+315 \mathrm{~F}-15.2 \mathrm{D} \quad \mathrm{R}^{2}=86.9 \% & \text { Equation } 6 \\
\mathrm{~T}_{[\mathrm{PS}]}=-934+233 \mathrm{~F}+40.4 \mathrm{D}-87.3 \mathrm{D} \times \mathrm{F} \quad \mathrm{R}^{2}=84.7 \% \quad \text { Equation } 7
\end{array}
$$

More assimilates partitioned from rhizomes into the tubers in the lower density (D) $\times$ intercrop (IC) treatments for all fertilizer rates, and similarly, more assimilates partitioned for the shoot into rhizome, even though the LAI was lower. This finding suggests that the shade of the intercrop did not decrease the activity of photosynthesis, but the partitioning of assimilates from the shoot to rhizome, and from rhizomes into tubers was improved. Further, fertilizer application of $0.5 \mathrm{t} / \mathrm{ha}$ of 13:23:13 at the crop density of 20.8 thousand plants per hectare realized the highest dry matter yield (1,066 g/plant).

The dry matter production and tuber yield of leren is dependent on the balance between photosynthesis and partition of assimilates, as 
photosynthesis in leaves can be strongly influenced by sink demand (Gifford and Evans, 1981; Gifford, 1986). The study suggests that in leren, the rhizome and tubers are the primary and secondary sinks, respectively, with distinct partitioning of assimilates from shoot to rhizomes and from rhizomes to tubers.

Increasing the quantity and rate of the photo-assimilates partitioned into the edible parts is an important crop efficiency criterion (Dincon and Zimdhal, after Hendrix, 2002). As such, the manipulation of crop husbandry practices has resulted in an increased dry matter yield in leren through crop density, fertilizer, and shading.

The leren rhizomes function as a storage reserve for starch. Environmental variables, including light intensity (shade/sunlight), cropping systems (pure stand/intercrop), and nitrogen levels influence the rates at which rhizomes are induced to form harvestable tubers.

\section{LITERATURE CITED}

Bridgemohan, P., 2009. Yield improvement studies in Calathea allouia (Aubl.) Lindl. Abstract presented at the 45th Annual Caribbean Food Crops Society Meeting, Federation of St. Kitts and Nevis, July 12th to 19th, 2009. Vol 45. p. 117.

Bridgemohan, P., 2010. Agro-economic assessment of Leren [Calathea allouia (Aubl.) Lindl] production in Trinidad and Tobago. Paper presented at the 46th Annual Caribbean Food Crops Society Conference Meeting, Boca Chica, Dominican Republic, July 11 th to 17 th, 2010.

Evans, L. T., 1978. The physiological basis of crop yield. In: Evans, L. T. (ed.). Crop Physiology. University of Cambridge Press. P. 327-355.

Evans, L. T., 1986. The physiology of Crop Plants. Field Crop Research 14: 173-174.

Everett, T. H., 1981. The New York Botanical Garden Illustrated Enclyopedia of Horticulture, Vol. 2. Gerland Publishing, Inc. New York, p. 550.

Gifford, R. M., 1986. Partitioning of photo-assimilates in the development of crop yield. In: Cronshaw J., J. L. Williams, T. G. Robert, eds. Phloem Transport. Alan R Liss, New York. 535-549.

Gifford, R. M. and L. T. Evans, 1981. Photosynthesis, carbon partitioning and yield. Ann. Rev. Plant Physiol. 32: 485-509.

Hendrix, J. E., 2002. Production-related assimilates transport and partitioning. In: Pessarakli M. (ed.). Handbook of Plant and Crop Physiology. 2nd edition. The University of Arizona, Tucson: A Marcel Derker, Inc. P. 421-448.

Hosfra, G. and C. D. Nelson, 1969. A comparative study of the translocation of assimilated ${ }^{14} \mathrm{C}$ from leaves of different species. Planta. Berl. 88: 103-112.

Johnson, K. B., S. B. Johnson and P. S. Teng, 1986. Development of a potato growth model for use in crop pest management. Agricultural Systems 19: 189-209.

Kay, D. E., 1973. Root crops. TPI Crop Products Digest 2. Tropical Products Institute, London, $245 \mathrm{pp}$.

Leahy, R. M., 1991. Bacterial leaf spots of Calathea spp. Plant Pathology circular No 345. Fla. Dept. Agric and Consumer Services, Division of Plant Industry. 
Martin, F. W. and E. Cabanillas, 1976. Leren (Calathea allouia), a little known tuberous root crop of the Caribbean. Economic Botany 30: 249-256.

Peel, A. J. and L. C. Ho, 1970. Colony size of Tuberlachnus salignus in relation to mass transport of ${ }^{14} \mathrm{C}$ labeled assimilates from leaves in willow. Physiol. Plantar. 23: 10331038.

Tan, W. and G. D. Hogan, 1968. Dry weight partitioning in relation to substrate supply, internal $\mathrm{N}$ status, and developmental stages in Jack Pine: Implications for modeling. Annals Botany 81: 195-201.

VaDelden, A., 2001. Yield and growth components of potato and wheat under organic nitrogen management. Agronomy J. 93: 55-66.

Struik, P. C., 2007. Responses of the potato plant to temperatures. In: D. Vreugdenhil et al. (eds.). Potato Biology and Biotechnology. p. 367-393.

Yin, X. and A. H. C. H. Schapendonk, 2004. Simulating the portioning of biomass and nitrogren between root and shoot in crop and grass plants. NJAS-Wageningen Journal of Life Sciences 51: 407-426. 